\title{
Indifferent but Mobilized: Rural Politics during the Interwar Period in Eastern and Western Europe
}

Daniel Brett

School of Slavonic and East European Studies, University College London, London, United Kingdom and Faculty of Arts and Social Sciences, Open University, Milton Keynes, United Kingdom

Daniel Brett, UCL School of Slavonic and East European Studies, University College London, Gower Street, London, WC1E 6BN daniel.brett@ucl.ac.uk 


\section{Indifferent but Mobilized: Rural Politics during the Interwar Period in Eastern and Western Europe ${ }^{1}$}

What did peasants discuss at party meetings? Were they mobilized by ethnic politics or indifferent to them altogether? The end of the First World War brought about universal male suffrage in much of Europe, and with it the process of mass politics began. The concept of national indifference is important in understanding interwar politics, because this period is often studied teleologically with attention focused on extremism and nationalism as the primary mobilizing issue Agrarian movements have been under-researched, and when Agrarians have been studied, it has been through the prism of elite politics. This comparative paper seeks to redress this omission by looking at grassroots rural politics. The interwar countryside was marked by profound political, economic and social transformation but also in terms of what Robert Paxton has described as the 'triple crisis of the countryside' - worsening economic conditions, the declining status of the countryside and inadequate political representation. The paper will explore how reform and crisis impacted how agrarian politics functioned at a local level by asymmetrically comparing cases from Romania, Poland and Ireland, with the final case helping to contextualize Eastern Europe within the wider European experience This paper argues that the rural population was mobilized, but primarily in the context of local issues rather than national ethnopolitical questions. Local party organization was, to paraphrase James C Scott, the site 'of an exchange of small arms fire' in rural class conflict, as questions regarding the control of public space, generational conflict and power within the village mobilized peasants. Thus, I argue that it was the underlying socioeconomic issues that mobilized the rural population, not nationalism. The

${ }^{1}$ An early version of this paper was originally presented at "The concept of "national indifference' and its potential to nations and nationalism research" workshop held in Prague, 5-6 $6^{\text {th }}$ September 2016. I would like to thank Pieter Judson, Tara Zahra, Jeremy King, James M. Brophy, Jim Bjork, Jon Fox and Peter Bugge for their comments. I would also like to thank Dennis Deletant, George Kolankiewicz, Trevor Thomas, Irina Marin, Seán Hanley, Martyn Rady, Diana Dumitru, Svetlana Suveica, Angela Harre, Tony Varley, Helen O'Shea, Warren Carter, Amy Samuelson, and Heidi Samuelson. 
dynamics of these conflicts were shaped by local economic, political and social power dynamics, and by using indifference as a concept, we can look more deeply at interwar politics from a grassroots perspective and develop a more nuanced understanding of local, national and European politics.

Keywords: agrarianism; rural politics; transition; Romania; Poland; Ireland

Introduction

Rural politics is one of the forgotten backwaters of twentieth century history. While we have extensive studies of parties of the left and right, the Agrarians mark a blank spot in the literature. ${ }^{2}$ Barrington Moore described the peasantry ${ }^{3}$ as a 'class over

2 The key works on Agrarianism remain: Heinz Gollwitzer, Europäische Bauernparteien im 20. Jahrhundert (Stuttgart and New York,1977) and Derek Urwin, From Ploughshare to Ballotbox: The Politics of Agrarian Defence in Europe (Oslo, 1980). There have been more recent regional studies such as David Arter, (ed) From Farmyard to City Square? The Electoral Adaptation of the Nordic Agrarian Parties (Aldershot, 2001), Helga Schulz, and Angela Harre. Bauerngesellschaften Auf Dem Weg in Die Moderne: Agrarismus in Ostmitteleuropa 1880 Bis 1960. (Wiesbaden, 2010) and Alex Toshkov, Agrarianism as Modernity in 20th-Century Europe: The Golden Age of the Peasantry (London, 2019). See also Angela Harre, Wege in die Moderne: Entwicklungsstrategien rumänischer Ökonomen im 19. und 20. Jahrhundert (Wiesbaden, 2009) and Sorin Radu and Oliver Jens Schmitt Politics and peasants in interwar Romania: Perceptions, mentalities, propaganda (Newcastle upon Tyne, 2017); for Ireland see Tony Varley and Peter Moser, 'Clann na Talmhan: Ireland's Last Farmers' Party', History Ireland 3 no.2 (1995), pp.39-43. Tony Varley, 'On the Road to Extinction: Agrarian Parties in Twentieth-Century Ireland', Irish Political Studies 25 no.4, (2010), pp.581-601; Jason Knirck ““A Regime of Squandermania': The Irish Farmers' Party, Agriculture and Democracy, 1922-27," in Mel Farrell, Jason Knirck and Ciara Meehan (eds.), A Formative Decade: Ireland in the 1920s (Dublin, 2015), pp.177-197.

${ }^{3}$ As Robert Moeller notes, defining who is a farmer and who is a peasant varies, reflecting the stratification of that area based on a number of different factors. Robert G. Moeller, German 
whom the waves of progress are about to roll, ${ }^{4}$ suggesting a powerless social group devoid of agency, while Marx talked of undifferentiated 'homologous magnitudes, much as potatoes in a sack form a sack of potatoes. ${ }^{5}$ Rural society was assumed to be a place where politics does not happen, but politics happens to it, and, thus, rural society was not politically mobilized. For nationalists and those in nationalism studies, this lack of politics is seen most sharply in questions of national identity and having a consciousness of a national identity. ${ }^{6}$ As Jan Słomka, a Polish peasant who rose to be mayor of his village, notes in his memoirs:

"As for national consciousness, I have mentioned that the older peasants called themselves Masurians, and their speech Masurian. They lived their own life, forming a wholly separate group, and caring nothing for the nation. I myself did not know I was a Pole until I began to read books and papers, and I fancy that other villagers came to be aware of their national attachment much the same way." 7

However, the nineteenth and twentieth centuries saw an increasing politicisation of the countryside 'when individuals or communities perceive[d] the links between local

Peasants and Agrarian Politics, 1914-1924: The Rhineland and Westphalia (Chapel Hill, 1986).

${ }^{4}$ Barrington Moore, Social Origins of Dictatorship and Democracy: Lord and Peasant in the Making of the Modern World (Harmondsworth, 1967), p.507.

${ }^{5}$ Karl Marx, The Eighteenth Brumaire of Louis Bonaparte, (Moscow, 1977), p.106.

${ }^{6}$ The relationship of rural society with state and nation builders has been studied extensively, all taking Eugen Weber as a starting point. See Eugen Weber Peasants into Frenchmen: The modernization of rural France, 1870-1914 (London, 1977). For a recent example see Andrei Cusco. 'Russians, Romanians, or Neither? Mobilization of Ethnicity and "National Indifference" in Early 20th-Century Bessarabia.' Kritika: Explorations in Russian and Eurasian History 20. 1 (2019): pp.7-38. Here the peasantry is an object devoid of agency or voice for nationalist intellectuals and activists to mobilise.

${ }^{7}$ Jan Słomka, From Serfdom to Self Government, Memoirs of a Polish Village Mayor 18421927, (London, 1941), p.171. 
events and the problems of private life, on the one hand, and national political events and structures on the other. ${ }^{18}$ This process resulted in the emergence of Agrarian movements that claimed to represent rural society. The responses to these movements varied in form and content. Anu-Mai Kõll argues that the nature of Agrarian politics is shaped by the dynamics of ethnicity and class. In particular, if the ethnicity of the local landlord class was different from that of the peasantry, then Agrarianism with a mobilising discourse framed around nationalism emerges, but where the ethnicity of the landlord class and the peasantry coincide, then the mobilising discourse was built on economic class differences. ${ }^{9}$

In Ireland, for example, the land question is understood as intertwined with the national question. ${ }^{10}$ However, this tends to downplay economic diversity and conflict within rural society. There was as much tension between small-scale Irish tenant farmers and medium-scale tenant farmers before 1918 as there was between tenants and landlords. ${ }^{11}$ Furthermore, different forms of farming produce different economic relations and interests (subsistence farming, small-scale farming, etc), which often conflict with one another, and these also tend to be regionally concentrated and thus

${ }^{8}$ Suzanne Berger, Peasants against Politics: Rural Organization in Brittany 1911-1967, (Cambridge, MA, 1972), p.34.

${ }^{9}$ Anu-Mai Kõll, 'Agrarianism and Ethnicity', in Helga Schultz, and Eduard Kubů, History and Culture of Economic Nationalism in East Central Europe, (Berlin, 2006).

${ }^{10}$ The relationship between the land question and Irish nationalism in the Nineteenth century has generated a great deal of literature. For a summary see: Joseph Coohill, Ireland: A short history ( $4^{\text {th }}$ ed.) (Oxford, 2014) pp.90-94. For more detail see Fergus Campbell and Tony Varley (eds) Land questions in modern Ireland, (Manchester, 2013).

${ }^{11}$ Paul Bew, Land and the National Question in Ireland 1858-1882, (Atlantic Highlands, 1978). 
localized. ${ }^{12}$ These tensions, which are primarily based around economic concerns, are what dominate everyday rural politics rather than the grand questions of national identity.

Taking up the idea of 'national indifference', ${ }^{13}$ this paper argues that while questions of identity may not have been a feature of everyday peasant life, this does not mean that peasants did not think or talk about politics. In fact, the reverse is true: I will argue that rural society was highly mobilized and that the political world beyond elite politics at the centre was vibrant and rich, and orientated towards local and rural concerns. The expansion of the electoral franchise before and after World War I opened up new possibilities for contention. As Charles Tilly ${ }^{14}$ has shown, there are always moments of contention, but the forms that they take change as political, economic and social transformation takes place. Thus, local parties represent a new contentious space. Taking James C Scott's point that party politics in the village was a frequent site of 'small arms fire' in rural class conflict, ${ }^{15}$ I argue that rural populations were largely

${ }^{12}$ For examples see: Doreen Warriner, Economics of Peasant Farming, ( $2^{\text {nd }}$ Edition) (London, 1964); Gordon Wright, Rural Revolution in France: The Peasantry in the Twentieth Century, (Stanford, 1964); Bew, Land and the National Question in Ireland; Mark Cleary, Peasants, Politicians and Producers: The Organization of Agriculture in France since 1918. (Cambridge, 1989); Robert Paxton, French Peasant Fascism: Henry Dorgères 's Greenshirts and the Crises of French Agriculture, 1929-1939, (New York, 1997)

${ }^{13}$ Tara Zahra, 'Imagined Non-communities: National Indifference as a Category of Analysis', Slavic Review, 69, no.1 (2010), p.97.

${ }^{14}$ Charles Tilly, 'Contentious Repertoires in Great Britain, 1758-1834.' Social Science History 17 (1983), pp. 253-80.

${ }^{15}$ James C. Scott, Weapons of the Weak: Everyday Forms of Peasant Resistance, (New Haven, 1985), p.1. 
agnostic $^{16}$ to their nations but were highly politicized and had an acute awareness of local and national politics. Their political engagement was primarily oriented to their own rural worlds, they used and interacted with national politics. Rural populations and parties deployed national politics by using it as a prism through which their own local battles could be viewed. ${ }^{17}$ National politics was not at the forefront of rural politics, but rather it was used selectively. As we shall see, when peasants did engage or respond to national politics, it was not in the context of questions of identity or questions of democracy, but often in economic terms. Moreover, and perhaps most importantly, this was an autonomous, bottom-up process, instigated by peasants in the village, reflecting both political sophistication and agency.

I focus my attention on the main Agrarian parties of Romania, Poland and Ireland during the interwar period. These parties reflected mainstream politics during the period and strived to represent the largest social group in their respective societies; and, thus, they were in the strongest position to act as intermediaries between the elite and the population.

\section{Finding Peasant Voice}

The methodology used in this paper is influenced by the nature of the material available. Restoring peasant voices is a difficult process. In the case of Central and Eastern Europe, the situation is made more complex by the suppression of democratic political

${ }^{16}$ Tara Zahra. Kidnapped souls. National indifference and the battle for children in the Bohemian Lands, 1900-1948, (Ithaca, 2008).

${ }^{17}$ For an alternative viewpoint, see Jeremy King Budweisers into Czechs and German: a local history of Bohemian politics, 1848-1948, (Princeton: 2002) and James E. Bjork Neither German nor Pole: Catholicism and national indifference in a Central European Borderland, (Ann Arbor, 2008). 
organizations before World War II and the subsequent Communist repression. ${ }^{18}$

However, it would be wrong to attribute the lack of material to repressive destruction. Rural society was predominantly an oral society and low levels of literacy meant that record keeping was limited. The very few surviving records are spread diffusely. ${ }^{19}$ In the case of Romania, the interwar Partidul Naţional Ţărănesc (National Peasant Party) (PNŢ) does not appear to have possessed a formal archive or record of discussions, in part because of the informal organization of the PNT, and in part because, as Paxton notes, literacy was associated with modernity, and for many rural conservatives (who made up much of the party elite), this was seen as a threat to the status quo; orality was a way of rejecting the modern world. ${ }^{20}$ The records that do survive were the result of individual initiatives by local organizations or individual actors. They are often

${ }^{18}$ A Romanian secret police report about the documents relating to PNT found when requisitioning the house of Dr. Victor Macavei states: 'Intrucât materialul de mai sus nu poate fi exploatat deoarece este vechi şi fără importanţă, suntem de părere să fie distrus prin ardere' ('Because the above-mentioned material cannot be used as it is old and without importance, we are of the opinion that it should be destroyed by burning'). See Arhiva Consiliului Naţional pentru Studierea Arhivelor Securității, Bucharest, Romania, Fond D, dosar 8827/2, pp. 245-46.

${ }^{19}$ Limited material relating to local party organization in Ireland can be found in the Clann na Talmhan, Castlebar Sub-Executive Minutes, November 1942 - April 1960, Mayo County Library, Castlebar, MS 354/415 and the letters of George O'Callaghan-Westropp (18641944), University College Dublin Archives, IE UCDA P38, which provide a snapshot of the everyday workings of the two Irish Agrarian parties.

${ }^{20}$ Dennis Deletant to D.B. When Corneliu Coposu was specifically asked in August 1986 about the existence of a PNT archive, he replied that he was not aware that such a thing ever existed. Both Coposu, and later Constantin (Ticu) Dumitrescu (who was also an active member of PNT before 1947) noted that minutes of central committee meetings of the PNT were rarely taken; See also Paxton, French Peasant Fascism, p.8. 
fragmentary and their survival accidental.

Thus, any material gives us merely a snapshot of rural life. For this reason, one has to adopt an approach resembling bricolage to fill the gaps. It may be asked how representative this material is of village experience, however. As Clifford Geertz notes,

\begin{abstract}
"villages are peculiar, complicated, and extraordinarily diverse. There is no simple uniformity $[\ldots]$ to be found over the whole of the small, crowded countryside, no straightforward form of village organization easily pictured in terms of single typological construction, no 'average' village, a description of which may well stand for the whole. Rather, there is a set of marvelously complex [...] systems, no one of which is quite like any other, no one of which fails to show some marked peculiarity of form. [...] Yet all these small-scale systems are clearly of a family. They represent variations, however intricate, on a common set of organizational themes, so that what is constant in Balinese village structure is the set of components out of which it is constructed, not the structure itself." 21
\end{abstract}

The material that exists represents neither typical nor unique examples of rural politics, but rather examples of the component parts.

As a result of the problems associated with archival material, this paper will contain an asymmetrical comparison. ${ }^{22}$ Romania will be the primary case, with Ireland and Poland providing comparative examples. This will help avoid the potential problem of exceptionalizing Romania. Ireland and Poland will be used as control cases and as a mise-en-scene, given the sharing of salient political and social issues. These cases have

${ }^{21}$ Clifford Geertz, 'Form and Variation in Balinese Village Structure', American Anthropologist 61, no.6 (1959), p.991.

22 Jürgen Kocka, 'Asymmetrical Historical Comparison: The Case of the German Sonderweg', History and Theory 38, no. 1 (1999), pp.40-50; Jürgen Kocka, 'Comparison and Beyond', History and Theory, 42 no.1 (2003), pp.39-44; Michael Werner and Bénédicte Zimmermann. 'Beyond Comparison: Histoire Croisée and the Challenge of Reflexivity.' History and Theory, 45, no. 1, (2006), pp.30-50. 
been chosen because they are all on the periphery of Europe. Agriculture was the primary industry employing $72.3 \%$ of the Romanian population in $1930,60.6 \%$ of the Polish population in 1931 and 51.4 of the Irish labour force in $1926 .{ }^{23}$ All were undergoing political, economic and social transformation during the interwar period: they were either new or unified states which had been locked into imperial economic systems, and they were all subject to new political centres emerging and seeking to exert new forms of control over the countryside. Furthermore, it allows us to see rural society in a broader European context rather than narrow state or regional intellectual silos. To accomplish this, the paper draws on archival material from the village of Berlişte in the Banat on the border with Romania and what was then Yugoslavia; from Soroca and Tighina in Bessarabia, on the border with Romania and the Soviet Union; from the personal archive of Col. George O'Callaghan-Westropp, a landowner and activist from East Clare in Western Ireland; and from party records from the local Clann na Talmhan organization in Castlebar in County Mayo in Western Ireland.

There are downsides to using this type of comparison. Even in its asymmetric form, comparison can lead to, according to Jurgen Kocka 'questions that cannot otherwise be posed and to answers that cannot otherwise be given' ${ }^{24}$ Moreover, asymmetric comparisons can work as a self-correcting device by motivating further

\footnotetext{
${ }^{23}$ Data for Romania and Poland taken from Joseph Rothschild, East Central Europe between the Two World Wars, (Seattle, 1992), pp.39 and 285; The data for Ireland is for those listed as working in agriculture and is drawn from the 1926 Irish Census. Saorstát Éirean Census of Population 1926. Vol II, Occupations of Males and Females in each Province, County Borough, Urban and Rural District, (Dublin, 1928). https://www.cso.ie/en/media/csoie/census/census1926results/volume2/C_1926_V2.pdf (Date accessed 6th February 2019).

${ }^{24}$ Kocka, 'Asymmetrical Historical Comparison', p.49.
} 
empirical research. Giovanni Sartori has argued that combining comparison and case studies 'can well be mutually reinforcing and complementary undertakings' ${ }^{25}$

There are several functions of asymmetrical comparison: heuristic, analytical and, as noted earlier, 'deprovincializing'. ${ }^{26}$ I add a fourth one: the compensatory, ancillary function. Thus, the Irish and Polish cases provide cognate cases on which analogies can be drawn and extrapolations be made in order to compensate for bibliographical and archival gaps.

Agrarian Parties as Organizations

One reason why rural politics and Agrarian parties have been overlooked is because of the difficulty of defining what Agrarianism is. Barral defines Agrarians as 'farmers fighting to defend their place in industrial society'. ${ }^{27}$ However, this does not quite capture Agrarianism. I use a broad definition of Agrarianism, defining Agrarian parties as any party which claims to speak for the rural population and to prioritise rural society. I use the term 'Agrarian parties' to refer to the above-mentioned political organizations and to similar ones across Europe as a generic designation, which, captures, the nature of these parties. To call them peasant parties or movements would be to convey the erroneous impression that they were formed of or run by peasants, which they were not, and to describe them as farmers' parties would give an inaccurate account of rural society. In the Romanian case, the adjective ţărănesc (peasant) is used and not the plural genitive noun ţăranilor, (peasants) which suggests that this was not a

\footnotetext{
${ }^{25}$ Giovanni Sartori, ‘Comparing and Miscomparing', Journal of Theoretical Politics 3 no. 3 1991, pp.243-257.

${ }^{26}$ Kocka, 'Comparison and Beyond', pp.40-41.

${ }^{27}$ Pierre Barral, Les Agrariens Français de Méline à Pisani, (Paris: 1968), p.13.
} 
peasants' party but rather a party relating to or concerning itself with the peasant and land questions. In Poland, Stronnictwo Ludowe literally translates as the People's Party (alternatively rendered as the Peasant Party). ${ }^{28}$ In the case of Ireland, the Farmers' Party (active 1922-1932) is inconsistently rendered as both Farmers' Party and Farmers Party, while its successor Clann na Talmhan (active 1938-1965) translates as Children of the Soil/Land but was also called the National Agricultural Party.

Many of the parties had their roots in organizations and networks that were formed prior to the expansion of the franchise. The structure of those older organizations was geared towards conducting politics within a limited electoral franchise. The Hungarian franchise, which covered Transylvania and the Banat, was limited to a mere 6 percent of the population. ${ }^{29}$ In Galicia, the electoral college system was structured to weaken the power of the countryside. It was divided into rural and urban colleges with the rural college covering the countryside but also small towns. In addition, the majority of the voters were larger-scale farmers and part of the richer population. ${ }^{30}$ As Olga Narkiewicz notes:

\footnotetext{
"In 1883 , out of $1,418,000$ smaller farmers only 537,000 paid high enough taxes to vote in the primaries. Eight hundred thousand male peasant workers were deprived of electoral rights because of property qualifications; about one million male
}

${ }^{28}$ At various times there were competing parties using the term PSL and distinguishing themselves by using different suffixes - in 1913, PSL in Galicia had split leading to the formation of PSL Piast (1913-1931) and PSL Lewica (1913-24). PSL Wyzwolenie (1915-31) emerged separately. In 1931, PSL Piast, PSL Wyzwolenie and Stronnictwo Chłopskie (Peasant Party) (1926-1931) merged to form Stronnictwo Ludowe (SL), after 1945, SL readopted the name PSL to distinguish itself from a Communist front party.

${ }^{29}$ Andrew Janos, The Politics of Backwardness in Hungary 1825-1945. (Princeton, NJ: 1982), p.212.

${ }^{30}$ Olga Narkiewicz, The Green Flag Polish Populist Politics, 1867-1970 (London: 1976), p.20. 
peasant voters were deprived of the franchise because they were under thirty years old, and, additionally, about 3 million peasant women had no electoral rights at all. ${ }^{31}$

Thus, this inequality fostered a perception of the system as structured against the peasants and the idea that participation in the system was pointless. Słomka writes of his experience of pre-universal suffrage elections:

"Elections interested the peasant little, scarcely anything was said about them, nor were questions asked. And when something came up the answer would be: 'What do I care who is deputy, let them choose whom they will! [...] The lord will hold with his kind, so what can be done? Better keep out of it."”32

The expansion of the franchise before and after World War I, ${ }^{33}$ parties had to transform themselves into mass organizations and to recruit peasant voters. Peasants were now the single largest group of voters and in a position to shape national elections and politics. Before the expansion of the franchise, parties took the form of what Maurice Duverger has described as 'cadre parties', which are essentially a limited informal network of notable persons whose position and power is reflective of their social status and prestige. ${ }^{34}$

${ }^{31}$ Ibid, p.39.

${ }^{32}$ Słomka, From Serfdom to Self Government, pp.168-170.

${ }^{33}$ Universal male suffrage was achieved in 1896/1907 in the Austrian half of Austria-Hungary including Galicia and Bukovina but not Tranyslvania or the Banat which was part of Hungary. 1871 in Germany and German Poland. 1917 in Russia including Russian Poland and Bessarabia. 1918 in Britain and Ireland, 1918 in Romania (which now included Transylvania and Bukovina) and Southern Dobruja, which had formerly been part of Bulgaria (and where universal male suffrage was not granted until after World War II) ${ }^{34}$ Maurice Duverger, Political Parties: Their Organization and Activity in the Modern State, (London: 1954), p.63. 
Post-enfranchisement, new parties on the left and right adopted 'mass party' forms of organization, where the number of members is of most importance and the distribution of power is highly formalized through institutional hierarchies. Many rural parties were caught in between, as pre-existing informally organized cadre parties that needed to transform themselves into organized mass parties but were prevented by the vested interests of those whose power and influence inside and outside the party stood to be reduced by any shift in organizational form. PNȚ suffered from this problem after its creation in 1926. It was the result of a merger between the Partidul Naţional Român (Romanian National Party) (PNR) with its powerbase in Transylvania and Partidul Ţărănesc (Peasant Party) (PȚ) from the Old Kingdom. The Transylvanian wing dominated the party leadership. The new national party drew its internal organization from the nineteenth-century Transylvanian Romanian national movement that had become PNR, while PT had only come into its own after 1918 with the expansion of the franchise. Internal party reform would have meant the erosion of the power of the Transylvanian elite.

After the merger there was unwillingness by local leaderships to cede any power to the party, and this presented an organizational problem. The solution at the town and village level was to maintain parallel organizations within the party, one PNR and one PTु. At the local level there were two presidents appointed - one honorary and the other 'actual' — as a compromise to satisfy all camps. This situation existed in Argeş, Iaşi, Muscel, Buzău and elsewhere. ${ }^{35}$

The preponderance of informal networks led to a devolved form of local party organization. There was no attempt to define how a local party organization should be

\footnotetext{
${ }^{35}$ Ioan Scurtu, Istoria Partidului Naţional Ţărănesc, (2nd Edition), (București: 1994), p.64.
} 
set up, who should set it up, how it should be organized, and there was little direction from the central party which was often equally ad hoc in its organization. It was left to local actors to set up and run the party as they saw fit, providing that the local party was loyal to the national party (although this was not always the case and defection of local branches en masse were common). The situation emerged where the organization of the party at the elite level retained their cadre party organizational forms with elements of mass party organization (such as local branches) bolted onto the structure. The decision to keep records was an individual decision made by each particular local branch. In the case of Ireland, it was down to local branches of the Farmers' Union to decide if they wanted to engage with politics and to support the Farmers' Party, ${ }^{36}$ then in November 1942

'delegates from branches of Farmers' Organization in Castlebar area which was called for the purpose of deciding if said branches should become aligned with the Clann na Talmhan organization., ${ }^{37}$ This gave local leaders autonomy in how the party was organized as well as recruitment and policies.

Looking for the Nation - Local Party Activity and Concerns

For many in the Agrarian movements, 'politics' was seen as a cause of division and hence a weakness in the movement. The Farmers' Party in its early years had a ban on discussing politics at party meetings,${ }^{38}$ and Clann na Talmhan described itself as a non-

\footnotetext{
${ }^{36}$ University College Dublin Archives, Dublin Ireland, P38.16: 302, George O'CallaghanWestropp (1864-1944).

${ }^{37}$ Mayo County Library, Castlebar, County Mayo, Ireland, MS 354/415: 2 Clann na Talmhan, Castlebar Sub-Executive Minutes, November 1942 - April 1960.

${ }^{38}$ UCDA P38.16: 300.
} 
political party. ${ }^{39}$ Politics as the Farmers' Party understood it referred to questions of Irish independence and religious issues, but O'Callaghan-Westropp notes that following the end of the War of Independence the ban was lifted. ${ }^{40}$

What emerges out of party records is the parallel worlds of the village politics and national politics. Discussions of the big questions of the day, or national politics are rare, and were often only mentioned in passing or not at all. O'Callaghan-Westropp makes no reference to the Easter Uprising, the Irish War of Independence, or the Irish Civil War. There is one reference to a family being held up during the Civil War, but there are no discussions about national politics. What dominates discussion are local issues and power struggles. O'Callaghan-Westropp's dealings with his tenants shows the declining power of the landlord in the years before and after World War I. The conflicts over access to land rents dominate his correspondence. ${ }^{41}$

Similarly, the Berlişte records in Romania make scant reference to national politics. When 'politics' is discussed in terms of policies and ideas, those concerns are almost entirely localized. ${ }^{42}$ As you would expect in local elections, their programmes

${ }^{39}$ Eugene Duggan, The Ploughman on the Pound Note: Farmer Politics in County Galway during the Twentieth Century, (Athenry, 2004), p.88.

${ }^{40}$ UCDA P38.16: 300.

${ }^{41}$ UCDA, P38.1: 52.

${ }^{42}$ For the way in which national and local politics have interacted, see Charles Tilly, 'Contentious Repertoires in Great Britain, 1758-1834', pp.253-80, and John Markoff, 'Peasants Help Destroy an Old Regime and Defy a New One: Some Lessons from (and for) the Study of Social Movements', American Journal of Sociology, 102. 4 (1997), pp. 1113-42; For historical local examples of contention see Irina Marin, 'Rural Social Combustibility in Eastern Europe (1880-1914): A Cross-Border Perspective.' Rural History, 28, 1 (2017), pp.93-113. See also Irina Marin, Peasant Violence and Antisemitism in Early Twentieth-Century Eastern Europe (London, 2018); For more recent examples see 
concerned improvements in the village such as drainage in the pig field, improving roads, and improving access to markets, all of which would be popular with the rural electorate. However, elections were infrequent. Between elections the primary concern was social control within the village, and one expression of this was the centrality of the brass band (fanfară).

The brass band served multiple functions in the village for the party. Above all it was a mechanism for the party to control social and political space in the village. The significance of the brass band is explained by Jan Słomka, who in his memoirs of rural Poland describes how the village musicians were crucial to all social events within the village. The band played at every wedding, funeral, baptism and holiday, and thus control of the band provided a mechanism for influencing the social life, recruitment and dissemination the party's message. ${ }^{43}$ Stauter-Halstead notes that public celebrations were one of the main contexts in the rural public sphere for working out the collective interests of the village. ${ }^{44}$ The desire of activists in Berlişte was to retain influence over the public space because, on the one hand, the brass band discharged a ritualistic function (performing at key events in village life such as weddings, baptisms and funerals), and, on the other hand, it had a celebratory and solemn function within secular power structures (the army had a brass band, the authorities canvassed using a brass band). Given these functions, the brass band came to connote prestige and

Amy Samuelson, Frustration and Creativity: Environmentalism in the Republic of Moldova. $\mathrm{PhD}$ Thesis, University of Wisconsin-Milwaukee (2013).

${ }^{43}$ Słomka, From Serfdom to Self Government, p.274.

${ }^{44}$ Keely Stauter-Halsted, The Nation in the Village. The genesis of peasant national identity in Austrian Poland. 1848-1914, (Ithaca: 2001), p.33. 
authority, lending weight to the event it accompanied. It became an instrument for dominating and manipulating the heavily ritualistic public space of the village.

The brass band was a source of prestige for the party and was the public face of the party in the village and the surrounding area. The reports emphasize its importance, noting the events and locations outside of the village where it played. For example in May 1929, the brass band was recorded as representing the village at a national meeting in Alba Iulia. Later in November 1929, it is noted as having led a procession in conjunction with the brass band of Mircovăţ, a neighbouring village. Its success demonstrated to villagers the strength of the party.

The second function is that of recruitment. The brass band belonged to the party. Thus, peasants recruited into the prestigious brass band were also recruited into the party. Indeed, it was the primary mechanism of recruitment. The importance of recruitment is highlighted in a meeting of 7 May 1934:

"The president informs them of the situation of our brass band, which is a branch of our organization. The members of the brass band are complaining that the members of the organization do not support them by enlisting the members of their families who are able to enter the brass band. They appeal to the members and point out the significance of the brass band, which had been set up with so many sacrifices. The question of the brass band will be discussed in the committee meeting as well." ${ }^{45}$

The issue of recruitment is mentioned again at the next recorded meeting on 13 May 1934:

\footnotetext{
${ }^{45}$ Arhivele Naţionale Caraş-Severin (Caraş-Severin National Archives, Caransebeş) Fond Organizaţia Partidului Naţional Ţărănesc, Comuna Berlişte.
} 
"as regards the present situation in the brass band, the members of the committee of the organization in general are again urged to give it all their support by enlisting more members." 46

Class and generational conflict could have a specific rural dimension in the countryside. Land reform programmes had opened up economic cleavages, as some peasants now had sufficient land to engage in market relations while the majority (in the case of Romania two-thirds) still lived at subsistence levels ${ }^{47}$ Alongside this there were pre-existing generational conflicts. Generational tensions were one of the key features of rural conflict and this had a profound impact on local party organization. Upward social mobility and the ability to access positions and status in the village was dependent upon the acquisition of maturity, ${ }^{48}$ but maturity was not biologically determined but rather socially defined. Adulthood began when the peasant had their own landholding independent of their parents. Because land was usually a limited resource and controlled by others, younger peasants were often frustrated by their inability to gain maturity and this led to tensions.

Power was thus hierarchically ordered along generational lines with prestige and status belonging to the senior generation, which manifested in a coercive power over those below them in the village hierarchy. As Dobrowolsky ${ }^{49}$ points out, the authority of the senior generation traditionally lay not only in their economic control of land and the means of production, but in their established knowledge and farming experience. For

\footnotetext{
${ }^{46}$ Fond Organizaţia Partidului Naţional Ţărănesc, Comuna Berlişte.

${ }^{47}$ Hugh Seton-Watson, Eastern Europe between the Wars, (3rd Edition) (New York: 1967), p.259.

${ }^{48}$ Bogusław Gałęski, Basic Concepts of Rural Sociology, (Manchester, 1972), p.65.

${ }^{49}$ Frances Pine, Kinship, Marriage and Social Change in a Polish Highland Village, $\mathrm{PhD}$ Thesis, University of London, 1988, p.118
} 
example, Słomka highlights how older peasants would challenge and berate younger peasants who attempted to change even the most basic of agricultural practices. ${ }^{50}$ Generational-based authority varied in the different strata of the village. The right of the senior generation to control labour and marriage, the capacity to provide and care for land, and the power stemming from these rights was less fully realized among peasants with smaller holdings. ${ }^{51}$

Older peasants or those with high status positions such as the village teacher often dominated the local parties by virtue of their status. With socio-economic transformation widening cleavages and new sources of power and status, the older generation felt challenged. This can be seen in Berlişte, where at the suggestion of the regional leadership, the local leaders were keen to prevent younger and potentially more radical peasants from standing in the elections, instead arguing that candidates should be 'leading men experienced in battle'. 52

The emphasis on recruitment to the brass band and not promoting young candidates reflect the desire of the party leadership to control younger peasants through the party. The brass band was another tool that the elite had to control the lives of younger peasants. This desire for control and recognition of the threat the younger generation posed to their power, explains why issues of control are so dominant in the reports.

Using the Nation

The village was not, however, isolated or unaware of national politics and the state.

\footnotetext{
${ }^{50}$ Słomka, From Serfdom to Self Government, pp.34-35.

${ }^{51}$ Pine, Kinship, Marriage and Social Change in a Polish Highland Village, p.119.

${ }^{52}$ Fond Organizaţia Partidului Naţional Ţărănesc, Comuna Berlişte, Report dated 7 May 1934.
} 
Records show constant interaction between the village and the state. Peasants were concerned about their relationship with the state, because in their experience the state took from them, either materially or spiritually. Mistrust of the state was not mistrust of the state as a thing but rather of the individuals who acted on behalf of the state. When questioned about the legal system, villagers responded with the view that laws are "just but not always well applied". ${ }^{53}$ Similar sentiments towards the application of laws are noted in the village of Belinţ in the Banat. ${ }^{54}$ Słomka notes similar attitudes in his own village in Poland. Thus, within the village there was widespread mistrust not so much of national politics or politicians, but rather of local officials representing the state.

The nation provided a prism through which peasants could explain these local conflicts. Just as nationalists instrumentalized the nation to serve their own ends, ${ }^{55}$ local rural actors did the same. In the case of Berlişte, the party was in dispute with the local mayor and notary, both of whom belonged to the rival Partidul Naţional Liberal (National Liberal Party, PNL). They saw their own battle with the mayor as mirroring the national conflict between PNT and PNL. National politics explained the conflict and foreshadows the outcome.

${ }^{53}$ Edit Fél and Tamas Hofer, Proper peasants: traditional life in a Hungarian village, (Chicago: 1969), p.362.

${ }^{54}$ Institutul Social Banat-Crişana, Anchetă monografică în comuna Belinţ, (Timişoara: 1938), pp.299-303.

${ }^{55}$ See Rogers Brubaker, Nationalism reframed: Nationhood and the national question in the New Europe, (Cambridge, 1996); Rogers Brubaker, Myths and misconceptions in the study of nationalism, in John A. Hall (Ed.), The State of the Nation: Ernest Gellner and the Theory of Nationalism, (Cambridge, 1998), pp. 272-306. Rogers Brubaker and David Laitin, Ethnic and Nationalist Violence, Annual Review of Sociology, 24 (1998), PP.423-452; Roger Brubaker, Ethnicity without groups, European Journal of Sociology / Archives Européennes de Sociologie / Europäisches Archiv für Soziologie, 43.2 (2002), pp. 163-189 p.167-168 and Rogers Brubaker, Ethnicity without groups. (Cambridge, Mass.: 2004) 
"President Ion Gropşian talks to the members, in fervent words, about the superhuman struggle waged by our party for the emancipation from the Liberal yoke; asks the members to calm down the population agitated as a consequence of despicable behaviour of the commune council headed by Mayor P. Mirc and Şolea the notary, for the final victory is not far, which is proved by the fact that even the high Regency sees the situation clearly." 56

The issue is referred to again in March 1928 and in April 1929, when the President reported that their complaint against the Mayor has been successful.

This invocation of national politics as a way to frame their own political issues appears several times:
"Mr. President Ion Gropşian, after pointing out the struggle the National Peasant Party is waging for lawfulness and honesty, in order to free the peasantry from the yoke of the Phanariot system, salutes the supporters of the party, who in the past fought under the banner of this party.
$[\ldots]$

After thanking the former committee for the wisdom with which they managed the agenda of the organization, the President declares elected the new committee and, after the pledge to the effect that they will keep secret all confidential decisions, he draws the attention of the newly elected committee to the struggle that must be unswervingly waged until the final victory." ${ }^{57}$

These are examples of peasants constructing a political world view. Their battle was part of a larger battle which was on the eve of the final victory. The invocation of the 'yoke of the Phanariot system' is notable because Berlişte was in the Banat and had been part of Austria-Hungary until 1918. The Phanariot system had never been in place in the Banat; rather it had been in place from 1711 until 1821 in the Principalities. ${ }^{58}$

\footnotetext{
${ }^{56}$ Fond Organizaţia Partidului Naţional Ţărănesc, Comuna Berlişte (15 February 1928)

${ }^{57}$ Fond Organizaţia Partidului Naţional Ţărănesc, Comuna Berlişte (10 $0^{\text {th }}$ March 1928)

${ }^{58}$ Keith Hitchins, A Concise History of Romania. (Cambridge: 2014) 55-57
} 
Despite this, the local leadership was able to invoke and use the idea of the oppressive Phanariot system, and this was understood by the party members as the rationale behind the party's behaviour. ${ }^{59}$ Here, the Phanariot system was understood as an exploitative economic system rather than ethnic terms. The leadership did not invoke Hungarian rule in the Banat as a reference point or the struggle for Romanian cultural and political rights that had taken place before 1918. For the party in the countryside it was easier to connect to a struggle against an economic system that they had never been a part of than to a struggle for political and cultural rights that had taken place in their own region, but had been limited to the urban intelligentsia and not the peasants.

One area where we might expect nationalism and ethnic politics to become obvious is in recruitment to the party. Discursively, PNȚ and PSL were ethnic parties that sought the vote of a single ethnic peasantry, rather than pan-ethnic peasant parties. At the elite level this took the form of not working with rural parties that represented other ethnic communities. PNȚ made no attempt to appeal to non-Romanian peasants, in contrast of other movements on both the left and right which often produced bilingual material. The PSL leadership under Wincenty Witos opposed land-reform because he feared that Ukrainian peasants would gain at the expense of Polish landlords, and it was

${ }^{59}$ A potential source for this may be the Romanian and Hungarian press in Transylvania and the Banat before 1918, which decried the backward and oppressive land system in the Old Kingdom. During the 1907 Peasant Uprising in the Old Kingdom, the Transylvanian Romanian language newspaper Tribuna denounced the 'Byzantine system of land tenure' Eugen Brote quoted in Marin Badea, Andrei Caciora, Nicolae Rosut, Eugen Gluck, Aradul şi Răscoala Ţărănilor din 1907: 70 ani. (Arad: 1977). It also described the uprising as an 'internal Plevna' (Plevna was one of the locations during the Russo-Turkish war where fierce fighting took place), suggesting that having gained independence from the external Ottomans, Romanians now had to fight a new war against internal oppressors. 
only when in prison with Ukrainians that his views shifted. ${ }^{60}$ The emergence of ethnic agrarian parties (Hungarian, Saxon, Ukrainian and so on) would appear to re-enforce the view that national identity rather than class identity was the primary unifier. In Berlişte, the party was ethnically Romanian. The records are in Romanian and names are in their Romanian form. The Banat was an ethnically mixed area, but Berlişte was 98.7\% Romanian in the 1930 census. It had been $95.1 \%$ in the 1910 census, suggesting that there was no switching identity for the census ${ }^{61}$. Although, the record keeping of the party reflects its informal nature, so complete membership lists are unavailable.

A different picture emerges in Bessarabia. Records from the youth wing of PNT from two different areas (Soroca and Tighina) show a very different approach. Both were on the border between Romania and the Soviet Union. Record-keeping and membership details are more complete than in Berlişte, and the records were kept in both Romanian and Russian. Party members include Romanians, Russians, Jews and women. ${ }^{62}$ The lead here was taken by the younger generation rather than the older generation, unlike in Berlişte, where the local teacher was the party leader. A possible reason for this is the low levels of literacy in Bessarabia before 1918. The older generation was illiterate, but the younger generation benefited from the expansion of education after unification. ${ }^{63}$ This gave them the opportunity to control the party

${ }^{60}$ Richard Crampton, Eastern Europe in the Twentieth Century - and After ( $2^{\text {nd }}$ edition), (London: 1997), p.51.

${ }^{61}$ V.E Árpád, Krassó-Szörény megye településeinek etnikai (anyanyelvi/nemzetiségi) adatai 1880-2002, (2008), p.19.

${ }^{62}$ Arhiva Naţională a Republicii Moldova, Chişinău, Moldova, Partidul Naţional-Ţărănesc Filiala Tighina, fond 1643, 1.2; Arhiva Naţională a Republicii Moldova, Chişinău, Moldova, Partidul Naţional-Ţărănesc Filiala Soroca, fond 1752, 1.3.

${ }^{63}$ Irina Livezeanu, Cultural Politics in Greater Romania. Regionalism, Nation Building and Ethnic Struggle 1918-1930, (Ithaca and London: 1995). 
administration at the expense of the older generation. In contrast to growing nationalism in elite politics in the 1930s, the local parties in Soroca and Tighina reflect an inclusionary approach to recruitment, demonstrating the variation in approach and the gap between the national leadership and local actors. There is no indication as to whether this was a conscious decision to transcend ethnicity, or simply something that peasants in an ethnically mixed area took for granted. Soroca and Tighina show evidence of more formal mass forms of party organization, whereas the more informal party institutions in Berlişte shows the continuation of cadre party organization.

Responding to the Nation

The interwar period was marked by the 'triple crisis of the countryside': worsening economic conditions, rural depopulation linked to the increasingly peripheral cultural status of the countryside in the nation, and the lack of effective political representation. ${ }^{64}$ Agrarianism and rural politics was above all a response to these crises by actors from the periphery who were becoming increasingly marginalised.

Significantly, the rural population responded to both national politicians and those who claimed to represent the rural community.

The Farmers' Party and later Clann na Talmhan emerged in Ireland as a direct result of the rural population believing that the national elite did not represent them. ${ }^{65}$ As future Clann na Talmhan leader Michael Donnellan noted, "the only ploughman that politicians are interested in is the ploughman on the pound note". ${ }^{66}$ As a result in post-

\footnotetext{
${ }^{64}$ Paxton, French Peasant Fascism, p.11.

${ }^{65}$ Tony Varley, 'On the Road to Extinction: Agrarian Parties in Twentieth Century Ireland', Irish Political Studies 25 no.4, (2010), p.585; Tony Varley and Peter Moser, 'Clann na Talmhan: Ireland's Last Farmers' Party', History Ireland 3 no.2 (1995), p. 39.

${ }^{66}$ Duggan, The Ploughman on the Pound Note, p.69.
} 
Independence Ireland, the drive to form new Agrarian parties was driven from below as a response to the conservatism of the nationalist parties.

"The revolution that dispatched the colonial power from the South of Ireland in 1922 had left the social order in the territory ceded to the new administration substantially intact. It was a social order of persons disinclined to contemplate any change other than the political chance which independence represented." 67

The conservatism of the elite did not mean that conservative rural activists did not fear the worst. Although he was a Protestant and British Army Officer, O'Callaghan-Westropp's greatest fear after the War of Independence and the Civil War was not sectarian conflict but rather radical land redistribution ${ }^{68}$. Ironically, this fear was misplaced, as the new Irish Government was deeply conservative in its economic and social policies. But the point is, his fears stemmed from his economic interests rather than any hostility to nationalists. O'Callaghan-Westropp saw the world through the prism of someone who lives in the periphery. For him, neither London before 1923 nor Dublin after 1923 really understand the rural world and particularly that of East Clare, and the elite at the national level were anti-Landlord. He resented all attempts to reduce his local power. His primary concerns were not ethnic or national but economic and over control of the local space.

O’Callaghan-Westropp's only passing mention of identity politics comes in relation to the 1918 East Clare by-election. O'Callaghan-Westropp reported having been to one of the hustings and been impressed with both candidates but noted that he could not vote for either because the candidates were Republicans while he was 'a King's man'. While Eugene Duggan's memoirs of rural politics in Galway also reflect the rural population's

\footnotetext{
${ }^{67}$ Brown, Ireland: A social and cultural history 1922-2002, p.9

${ }^{68}$ UCDA P38.4: 87-89.
} 
occupation with their economic interests and questions of control over resources. These interests also transcended any loyalties that may have existed between former comrades in the old IRA during the War of Independence. This is illustrated in the dispute between the farmers and local Senator and former IRA man Mark Killilea. ${ }^{69}$

Far from being a community over whom the waves of progress rolled, or disinterested in politics at a national level, rural society was profoundly interested in questions of economic and political development and above all in questions of their representation. It is hardly surprising that economic concerns are the priority of rural communities. Most people in rural society lived an economically liminal life, where a bad harvest or a collapse in prices could result in famine or the loss of property.

One of the features of rural life was that different areas have different types of farming, with each type producing its own economic and labour relations as well as concerns. Types of farming tended to be regionally concentrated. One of the problems that the Agrarians faced was that the parties tended to be dominated by one region (often the most economically powerful). Tensions emerged when actors in one region felt that the leadership was pre-occupied with the concerns of their own region at the expense of other regions. In Ireland both the Farmers' Party and CnT were seen by many in the poorer West of Ireland as representing the interests of the large cattle farmers in the East. ${ }^{70}$ In Eastern Europe, while these tensions had existed before the Second World War, dislocation caused by the war increased them. Stefan Korbonski

${ }^{69}$ Killilea attempts to exploit that he and the local farmers were old IRA comrades and that they should support him for this reason. The farmers reject this asserting that their interests as farmers are more important in deciding who to support. Duggan, Ireland: A social and cultural history 1922-2002, pp.150-164.

${ }^{70}$ Varley, 'On the Road to Extinction: Agrarian Parties in Twentieth Century Ireland' 
recounts the difficulty the PSL leadership had upon its return from exile in reestablishing control over the party. Many within the party did not accept the legitimacy of a leadership that had spent the war in the 'comfort' of exile. ${ }^{71}$ This is echoed in Markham's account of travelling with PNŢ deputy leader Ion Mihalache during the 1946 election campaign. ${ }^{72}$

Economic concerns were not the only concerns that local activists raised in response to leadership. They were acutely aware of wider political questions. What is significant is that they did not concern themselves with questions of nation or ethnicity. Reflecting the pre-existing generational tensions of the countryside, Seton-Watson highlights the frustration felt by younger peasants with the older leadership, in particular in their responses to increasing authoritarianism and nationalism. ${ }^{73}$ Party activists in Soroca in December 1937 wrote to the party leadership after they signed an electoral pact with the fascist Iron Guard condemning the decision. ${ }^{74}$ The pact had been signed because of PNŢ leader Iuliu Maniu's personal opposition to King Carol II. ${ }^{75}$ Carol had been becoming increasingly authoritarian following his return to the throne in 1930. The 1930s had seen increasing political instability and political fragmentation, including the emergence of antisemitic extremist parties becoming part of the political centre, of which the Iron Guard was the most notorious (and later turned on PNŢ, attacking and

${ }^{71}$ Stefan Korbonski, Warsaw in Chains. (London, 1959); Anita Prażmowska, Civil War in Poland, 1942-1948, (Basingstoke: 2004).

${ }^{72}$ Reuben Markham, Rumania under the Soviet Yoke, (Boston: 1949)

${ }^{73}$ Seton-Watson, Eastern Europe between the Wars, pp.212-215.

${ }^{74}$ Arhiva Naţională a Republicii Moldova, Chişinău, Moldova, Partidul Naţional-Ţărănesc Filiala Soroca, fond 1752 1.10.

${ }^{75}$ Rebecca Haynes, 'Reluctant Allies? Iuliu Maniu and Corneliu Zelea Codreanu against Carol II of Romania', Slavonic and East European Review, 85 no.1 (2007), p.105 - 134. 
murdering left wing leaders including the economist and ideologue Virgil Madgearu in 1940). ${ }^{76}$ For peasant activists in Soroca the decision to align the party with such a group was a betrayal. They asked the leadership 'how can you defend democracy by aligning with an enemy of democracy?' That the Iron Guard would turn on PNŢ in 1940 shows that the peasants had a more acute awareness of the implications and the threat that the Guard posed than the national leadership.

\section{Conclusions}

This article has shown that politics in the countryside across Europe during the interwar period was rich and vibrant, with local actors being highly mobilized and willing to articulate very specific interests within their community and to national elites. These interests took many forms: concerns over power and control of resources within the rural community, concerns over economic issues and concerns over questions of representation and democracy. The interests expressed were not monolithic but reflected the diversity of rural society and the heterogeneity of groups and interests. All three societies under discussion underwent profound political, social and economic transformation before and after World War I. This transition increased tensions within rural society and led to further conflict between groups. At the heart of issues driving rural politics were questions of economic interest and representation, and so the interest urban intellectuals had in questions of the nation or ethnicity seem to have scarcely registered with the rural population. The primary and dominant concerns were largely local in character and focused on power in the village and other local concerns; sometimes these were predicated around political sources of power as in the case of

\footnotetext{
${ }^{76}$ Keith Hitchins, Rumania: 1866-1947, (Oxford, 1994) p.463.
} 
Berlişte, or economic, as we see with O’Callaghan-Westropp.

What is clear is that while for national elites with an interest in rural issues, or for those who saw rural society as a useful group to mobilise, ethnic issues were a key component of discourse, especially where the landlords and peasants were of differing ethnicities, but even in ethnically diverse areas such as Transylvania, these discourses had little salience with the population. The rural world was agnostic to the nation because the nation was not the primary issue concerning their rural world. The existential threat to the peasant or tenant farmer was not from another ethnic community, but from a bad harvest, famine, a collapse in prices or an exploitative economic system, and this was understood by rural society itself. The rural world was indifferent to the nation because it had more pressing concerns and threats to its survival.

This is not to say that rural society was unaware of, or had no interest in, the nation or national politics. In fact, the reverse can be said: there were two forms of interaction with the nation and national politics. The first was to deploy the nation as a rhetorical and explanatory tool in which local actors could understand their struggles as a microcosm of the struggles taking place in the wider nation and that they were part of a wider whole. The 'nation' that was being deployed in this rhetoric was often a nation created by local actors. The second was through criticism of national politicians, including their own rural representatives, and the belief that those representatives were not serving the interests of rural society in the broader national politics.

What we see in part fits into the idea of repertoires of contention and action. Such repertoires involve the interaction of two of more actors, in each case it was local peasants against either the local party hierarchy, as in the case of Berliste and East Clare, against other local actors, as in the case Berliste, East Clare and Castlebar, or 
against the national leadership, as in the cases of Soroca and Tighina, Galway and East Clare. In each example the vehicle for these acts of contention to take place was through local party organization.

Rural communities were not demobilized, nor were they indifferent or disconnected from the nation or national politics: they were aware of the nation, they responded to the nation and they used the nation, but they did so on their own terms, to advance local issues and power struggles and to seek to improve the social, economic and political position of the countryside.

Archives

IE UCDA P38 George O’Callaghan-Westropp (1864-1944) University College Dublin Archives, Dublin Ireland

MS 354/415 Clann na Talmhan, Castlebar Sub-Executive Minutes, November 1942 April 1960, Mayo County Library, Castlebar, County Mayo, Ireland

Partidul Naţional-Ţărănesc Filiala Soroca, fond 1752 Arhiva Naţională a Republicii Moldova, Chişinău, Moldova.

Partidul Naţional-Ţărănesc Filiala Tighina, fond 1643 Arhiva Naţională a Republicii Moldova, Chişinău, Moldova.

ACNSAS, FOND D, dos. 8827/2 Consiliul Naţional Pentru Studierea Archivelor Securitaţii, Bucharest, Romania

Fond Organizaţia Partidului Naţional Ţărănesc, Comuna Berlişte Arhivele Naţionale Caraş-Severin (Caraş-Severin National Archives, Caransebeş)

\section{V.E Árpád, Krassó-Szörény megye településeinek etnikai (anyanyelvi/nemzetiségi)} adatai 1880-2002. (2008)

www.kia.hu/konyvtar/erdely/erd2002/csetn02.pdf

David Arter,(ed) From Farmyard to City Square?: The Electoral Adaptation of the Nordic Agrarian Parties (Aldershot: 2001)

Marin Badea, Andrei Caciora, Nicolae Rosut, Eugen Gluck, Aradul şi Răscoala Ţărănilor din 1907: 70 ani. (Arad: 1977) 
Pierre Barral, Les Agrariens Français de Méline à Pisani. (Paris: 1968)

Suzanne Berger, Peasants against Politics: Rural Organization in Brittany 1911-1967, (Cambridge, MA, 1972)

Paul Bew, Land and the National Question in Ireland 1858-1882. (Atlantic Highlands, 1978)

James E. Bjork Neither German nor Pole: Catholicism and national indifference in a Central European Borderland (Ann Arbor, 2008)

Terrance Brown, Ireland: A social and cultural history 1922-2002. (London: 2004)

Fergus Campbell and Tony Varley (eds) Land questions in modern Ireland,

(Manchester, 2013)

Mark Cleary, Peasants, Politicians and Producers: The Organization of Agriculture in France since 1918. (Cambridge: 1989)

Joseph Coohill, Ireland: A short history (4 ${ }^{\text {th }}$ ed.) (Oxford, 2014)

Richard Crampton, Eastern Europe in the Twentieth Century - and After ( $2^{\text {nd }}$ edition). (London: 1997)

Andrei Cusco. 'Russians, Romanians, or Neither? Mobilization of Ethnicity and "National Indifference" in Early 20th-Century Bessarabia.' Kritika: Explorations in Russian and Eurasian History 20 no.1 (2019) 7-38.

Eugene Duggan, The Ploughman on the Pound Note: Farmer Politics in County Galway during the Twentieth Century. (Athenry, 2004)

Maurice Duverger, Political Parties: Their Organization and Activity in the Modern State. (London: 1954)

Mel Farrell, Jason Knirck and Ciara Meehan (eds.), A Formative Decade: Ireland in the 1920s (Dublin, 2015)

Edit Fél and Tamas Hofer, Proper peasants: traditional life in a Hungarian village.

(Chicago: 1969)

Bogusław Gałęski, Basic Concepts of Rural Sociology. (Manchester, 1972)

Clifford Geertz, 'Form and Variation in Balinese Village Structure', American Anthropologist 61 no.6 (1959) 991-1012.

Heinz Gollwitzer, Europäische Bauernparteien im 20. Jahrhundert (Stuttgart, New York, 1977)

Angela Harre, Wege in die Moderne: Entwicklungsstrategien rumänischer Ökonomen im 19. und 20. Jahrhundert (Wiesbaden 2009) 
Rebecca Haynes, 'Reluctant Allies? Iuliu Maniu and Corneliu Zelea Codreanu against Carol II of Romania'. Slavonic and East European Review 85 no.1 (2007) 105 134.

Keith Hitchins, Rumania: 1866-1947. (Oxford; 1994)

Keith Hitchins, A Nation affirmed: The Romanian National Movement in Transylvania 1860-1914. (Bucharest: 1999)

Keith Hitchins, A Concise History of Romania. (Cambridge: 2014)

Institutul Social Banat-Crişana. Anchetă monografică în comuna Belinţ. (Timişoara: 1938)

Andrew Janos, The Politics of Backwardness in Hungary 1825-1945. (Princeton, NJ: 1982)

Jeremy King Budweisers into Czechs and German: a local history of Bohemian politics, 1848-1948 (Princeton: 2002)

Jürgen Kocka, 'Asymmetrical Historical Comparison: The Case of the German Sonderweg', History and Theory 38, no. 1 (1999) 40-50

Jürgen Kocka, 'Comparison and Beyond', History and Theory, 42 no.1 (2003) 33-44

Stefan Korbonski, Warsaw in Chains. (London, 1959)

Irina Livezeanu, Cultural Politics in Greater Romania. Regionalism, Nation Building and Ethnic Struggle 1918-1930. (Ithaca and London: 1995)

Irina Marin, 'Rural Social Combustibility in Eastern Europe (1880-1914): A CrossBorder Perspective.' Rural History, 28, 1 (2017) 93-113

Irina Marin, Peasant Violence and Antisemitism in Early Twentieth-Century Eastern Europe (London, 2018)

Reuben Markham, Rumania under the Soviet Yoke, (Boston: 1949)

John Markoff, "Peasants Help Destroy an Old Regime and Defy a New One: Some Lessons from (and for) the Study of Social Movements." American Journal of Sociology 102. 4 (1997): 1113-42.

Karl Marx, The Eighteenth Brumaire of Louis Bonaparte, Moscow: 1977

Robert G. Moeller, German Peasants and Agrarian Politics, 1914-1924: The Rhineland and Westphalia (Chapel Hill: University of North Carolina Press, 1986)

Barrington Moore Jnr, Social Origins of Dictatorship and Democracy: Lord and Peasant in the Making of the Modern World Harmondsworth: 1967

Olga Narkiewicz, The Green Flag Polish Populist Politics, 1867-1970 (London: 1976) 
Robert Paxton, French Peasant Fascism: Henry Dorgères 's Greenshirts and the Crises of French Agriculture, 1929-1939, (New York: 1997)

Frances Pine, Kinship, Marriage and Social Change in a Polish Highland Village, $\mathrm{PhD}$ Thesis, University of London. 1988

Anita Prażmowska, Civil War in Poland, 1942-1948. (Basingstoke: 2004)

Sorin Radu and Oliver Jens Schmitt Politics and peasants in interwar Romania: Perceptions, mentalities, propaganda (Newcastle upon Tyne, 2017) Amy Samuelson, Frustration and Creativity: Environmentalism in the Republic of Moldova. PhD Thesis, University of Wisconsin-Milwaukee. 2013

Giovanni Sartori, 'Comparing and Miscomparing', Journal of Theoretical Politics 3 no.3 1991 243-257.

Helga Schultz, and Eduard Kubů, History and Culture of Economic Nationalism in East Central Europe, (Berlin, 2006)

Helga Schulz, and Angela Harre. Bauerngesellschaften Auf Dem Weg in Die Moderne: Agrarismus in Ostmitteleuropa 1880 Bis 1960. (Wiesbaden: 2010)

James C. Scott, Weapons of the Weak: Everyday Forms of Peasant Resistance (New Haven, 1985)

Ioan Scurtu, Istoria Partidului Naţional Ţărănesc. (2 ${ }^{\text {nd }}$ Edition) (Bucureşti: 1994)

Hugh Seton-Watson, Eastern Europe between the Wars. (3 ${ }^{\text {rd }}$ Edition) (New York: 1967) Jan Słomka, From Serfdom to Self Government, Memoirs of a Polish Village Mayor 1842-1927, (London, 1941)

Keely Stauter-Halsted, The Nation in the Village. The genesis of peasant national identity in Austrian Poland. 1848-1914 (Ithaca: 2001)

Alex Toshkov, Agrarianism as Modernity in 20th-Century Europe: The Golden Age of the Peasantry (London, 2019).

Derek Urwin, From Ploughshare to Ballotbox: The Politics of Agrarian Defence in Europe (Oslo: 1980)

Tony Varley and Peter Moser, 'Clann na Talmhan: Ireland's Last Farmers' Party', History Ireland 3 no.2 (1995) 39-43.

Tony Varley, 'On the Road to Extinction: Agrarian Parties in Twentieth Century Ireland', Irish Political Studies 25 no.4, (2010) 581-601

Doreen Warriner, Economics of Peasant Farming. ( $2^{\text {nd }}$ Edition) (London: 1964)

Eugen Weber Peasants into Frenchmen: The modernization of rural France, 18701914 (London: 1977) 
Michael Werner and Bénédicte Zimmermann. 'Beyond Comparison: Histoire Croisée and the Challenge of Reflexivity.' History and Theory, 45, no. 1, (2006) 30-50

Gordon Wright, Rural Revolution in France: The Peasantry in the Twentieth Century, (Stanford:1964),

Tara Zahra. Kidnapped souls. National indifference and the battle for children in the Bohemian Lands, 1900-1948 (Ithaca, 2008)

Tara Zahra, 'Imagined Non-communities: National Indifference as a Category of Analysis', Slavic Review, 69 no.1 (2010) 93-119 